\title{
TITLE:
}

\section{SOME NEMERTEANS FROM THE COASTS OF THE KII PENINSULA}

$\operatorname{AUTHOR}(\mathrm{S})$ :

Iwata, Fumio

\section{CITATION:}

Iwata, Fumio. SOME NEMERTEANS FROM THE COASTS OF THE KII PENINSULA. PUBLICATIONS OF THE SETO MARINE BIOLOGICAL LABORATORY 1954, 4(1): 33-42

ISSUE DATE:

1954-11-20

URL:

http://hdl.handle.net/2433/174503

RIGHT: 


\title{
SOME NEMERTEANS FROM THE COASTS OF THE KII PENINSULA ${ }^{1)}$
}

\author{
Fumio IWATA
}

Akkeshi Marine Biological Station, Akkeshi, Hokkaido

With 3 Text-figures

This paper deals with twelve species of nemerteans from the coasts of the Kii Peninsula, middle Japan, including two ones which seem to be new to science and a previously unknown one from Japan. Though four of the species included here were collected by myself from the coasts of Shirahama and Kushimoto in the spring of 1951, the others were offered me for identification by the courtesy of Dr. H. UTinomi. The materials of the latter ones were partly represented already in the collection preserved in the Seto Marine Biological Laboratory of the Kyoto University and partly collected by Dr. Utinomi in 1951 to 1954 .

The list of the species is as follows:

Tubulanus punctatus (TAKAKURA)

Lineus piperatus (STIMPSON)

Lineus cancelli sp. nov.

Lineus geniculatus (Delle ChIAJE)

Lineus fuscoviridis TAKAKURA

Micrura bella (STIMPSON)

Cerebratulus marginatus RENIER

Baseodiscus hemprichi (EHRENBERG)

Nemertopsis gracilis $\mathrm{COE}$

Amphiporus punctatulus COE

Amphiporus insolitus sp. nov.

Tetrastemma verinigrum var. meridianum nov.

Before going further, I wish to express my sincere thanks to Dr. Huzio UTiNomI of the Seto Marine Biological Laboratory for his kindness in placing many materials at my disposal and the permission of publishing this paper.

1) Contributions from the Seto Marine Biological Laboratory, No. 236.

Publ. Seto Mar. Biol. Lab., IV (1), 1954. (Article 4) 
Tubulanus punctatus (TAKAKURA), 1898

Carinella punctata: TAKAKURA, 1898.

Tubulanus nothus: WHEELER, 1934.

Tubulanus punctatus: Yamaoka, 1940; Iwata, 1954.

One specimen was collected by UTINOMI from the north coast of the Seto Marine Biological Laboratory on April 22, 1952.

Distribution. Misaki and the coasts of Hokkaido, Japan; Saldanha Bay, South Africa (WheELER).

\section{Lineus piperatus (STIMPSON), 1855}

Meckelia piperata: Stimpson, 1855.

Lineus piperatus: STIMPSON, 1857; TAKAKURA, 1898; BürgER, 1904; YAMAOKA, 1940 b.

Habitat. Rather rarely found under stones between the tide marks (by UTINOMI).

Distribution. Kikaishima and Naha, Riukiu Islands, Shimoda, Misaki, and Enoshima.
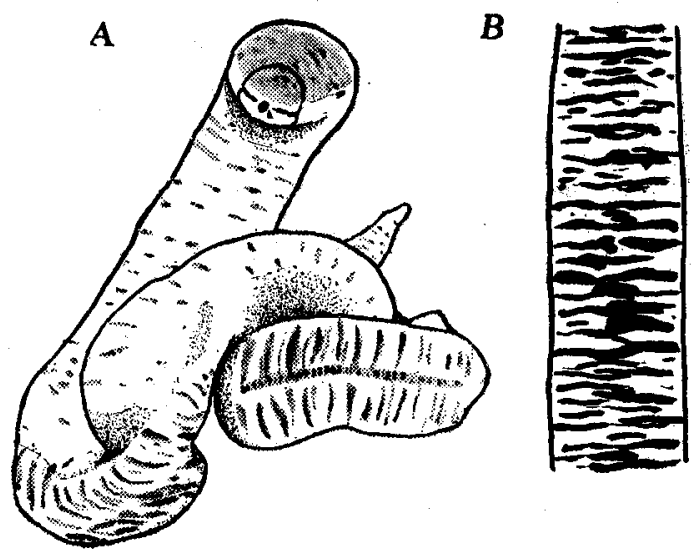

Fig. 1. Lineus cancelli sp. nov. A. Preserved state of the body. B. colouring of a part of the dorsal surface of the body.

\section{Lineus cancelli sp. nov.}

(Fig. 1)

The body is dull yellow in colour, marked with numerous dark brown transverse stripes which are irregularly arranged on dorsal surface of the body. They are divided into two lateral groups by the median line formed by short transversal stripes. On the ventral surface are irregularly scattered short transversal stripes. Ocelli wanting. The body in preservation is as follows: Of two specimens collected, one is shorter 
and broader, being about $6 \mathrm{~cm}$ long and $3 \mathrm{~mm}$ wide, while the other is longer and narrower, being about $12 \mathrm{~cm}$ long and $1-1.5 \mathrm{~mm}$ wide. Though the head is contracted into the body, furrows of the lateral cephalic grooves and the neck are recognized. The opening of the rhynchodaeum situated at the tip of the head forms a large pore. The mouth is indistinct. A longitudinal marking is also found along either side of the body in the smaller specimen. The distal end of the tail of the smaller one is abruptly narrowed and tapers to a point, but not forming the caudal cirrus as in the genus Micrura.

Internal structure. The epithelium is thin and a half the thickness of the circular muscle layer in oesophageal region. The cutis is not voluminous and not marked off from the outer longitudinal muscle layer. The connective tissue layer is wanting. The outer longitudinal muscle layer is about 2 times the thickness of the circular muscle layer in the oesophageal region. The pigment granules grouped into several masses are found around the body wall between the basal membrane and the cutis. The cephalic glands and the frontal organs are wanting. The lateral cephalic grooves are narrow and reach posteriorly the lateral side of the brain. The cephalic blood lacuna is not voluminous. The dorsal ganglion is about two times the size of the ventral ganglion and not divided posteriorly into two lobes. The cerebral sense organ extends backward into the lateral blood lacuna and is situated on the dorsal side of the lateral nerve cord. The mouth is represented by a short and narrow longitudinal slit and situated in a short distance from the posterior end of the cerebral sense organs. A pair of the oesophageal nerves runs posteriorly under the rhynchodaeum and is provided with a transverse commissure in front of the foregut. The proboscis is provided with three muscle layers (outer longitudinal) without the muscle cross. The proboscis sheath is limited to the anterior portion of the body. The nephridia are situated in the oesophageal region, and send out several efferent ducts towards the latero-ventral surface of the body.

Remarks. The present new species has characteristics quite different in the external feature of the body in the genus.

Habitat. Two specimens were collected under stones between the tide marks (by UTINOMI).

Distribution. Shirahama.

\section{Lineus geniculatus (DELLE CHIAJE), 1828}

Lineus geniculatus: BÜrger, 1895; COE, 1940; WHEELER, 1934.

Lineus digueti: JOUBIN, 1905.

Lineus mitellatus: TAKAKURA, 1895; IWATA, 1952.

The body is usually $30-60 \mathrm{~cm}$ long and $5-10 \mathrm{~mm}$ wide. It is rounded dorsoventrally in the anterior portion of the body and is flattened in the intestinal region. The head is flattened and becomes narrow anteriorly than the succeeding portion of 
the body, forming a spatula-shape from above. The middle portion of the tip of the head is protruded posteriorly. The body is variable in colour, being dark brown, purplish brown, dark purple, or bluish green. Many narrow white rings are found throughout the body. There were often found specimens without these rings in intestinal region. The first ring is situated at the middle portion of the head and thicker in width than any other ones, being protruded anteriorly in its middle portion on both the dorsal and ventral sides of the head. The tip of the head is white in colour. Though the ocelli are not observable from outside through the skin, many spots are arranged along the marginal portion of the head.

Internal structure. The cephalic glands and the frontal organs are wanting. The cutis glands are not well developed and one-third the thickness of the connective tissue layer in the portion of the mouth. The circular muscle layer is thick, being nearly same the thickness of the outer longitudinal layer in the anterior oesophageal region. The lateral cephalic grooves reach posteriorly the lateral side of the anterior portion of the brain. The cerebral sense organ extends backward to the lateral blood lacuna and is situated laterally to the lateral nerve cord. The dorsal ganglion is about two times the size of the ventral one and is divided posteriorly into two lobes. The cephalic blood lacunae are not extensive. The nephridia are provided with two pairs of efferent ducts opening externally through immediately above the lateral nerve cords. The proboscis sheath is limited to the anterior portion of the body. The proboscis is provided with two muscle layers (outer longitudinal) with two muscle crosses.

Remarks. The first record from Japan was reported under the name of $L$. mitellatus by TAKAKURA. He gave this name in recognition of the rings which entirely encircle both the dorsal and the ventral sides of the body without breaking in the middle portion of the dorsal side as in the European species L. geniculatus described by BÜRGER (1895), but this difference seems to me to be attributable to a local variation. The specimen having the same external feature of the body has been known from the coast of California by Joubin (1905) and from the west coast of Africa by WHEELER (1934). The internal structure of the present specimens agrees with that reported by BÜRGER, except the relative position of the cerebral sense organ and the lateral nerve cord.

Habitat. Rather commonly found under stones between the tide marks.

Distribution. Kushimoto, Shirahama (by UTINOMI and IwATA), Misaki (by TAKAKURA) and Tomioka, Japan; Mediterranean and Black Sea; west coast of Africa ; from the coast of California southwards to the west coasts of Mexico and Panama.

\section{Lineus fuscoviridis TAKaKURA, 1898}

Lineus fuscoviridis: TAKAKURA, 1898; IWATA, 1952.

The specimens of this form were collected on Mar. 9, 1954 by Dr. Kikutaro BABA 
at Kada, where it is commonly found.

Distribution. Kada, Tomioka and Misaki.

\section{Micrura bella (STIMPSON), 1857}

Cerebratulus bellus: STIMPSON, 1857.

Micrura festiva : TAKakuRA, 1898.

Lineus striatus: GRIFFIN, 1898.

Micrura bella: COE, 1901, 1905 and 1940; YAMAOKA, 1940 a ; IwATA, 1954.

One specimen was collected by Dr. Utinomi at Yuzaki, Shirahama, on Aug. 22, 1954. The external feature is as follows: Body about $10 \mathrm{~cm}$ long and $2 \mathrm{~mm}$ wide. Head orange, while the rest of the body reddish orange with narrow white transverse bands on the dorsal surface. Ventral surface wholly white. Caudal cirrus present.

Remarks. The present form resembles in its external characters to $M$. bella described by YAMAOKA (1940a), though slightly differs in colour. YAMAOKA reported that one specimen of this form was collected at Kushimoto.

Habitat. Under stones.

Distribution. Shirahama, Kushimoto, Misaki, Muroran and Oshoro.

\section{Cerebratulus marginatus RENTER, 1804}

Cerebratulus marginatus: Bürger, 1895 and 1904; CoE, 1901, 1905 and 1940; YAMAOKA, 1940 ; Iwata, 1954.

One specimen was found by trawl from off the coast of the Kii Peninsula in March of 1950. The external feature of the body preserved in diluted formalin solution is as follows:- The body, about $70 \mathrm{~cm}$ long and $2 \mathrm{~cm}$ wide, is convex dorsoventrally in the anterior portion of the body and is much flattened in the intestinal region. The body is generally pale brown in colour and in the slightly elevated marginal portion it is more whitish than the remainder.

Distribution. Misaki and the coasts of Hokkaido, Japan; the Atlantic Ocean (Europe and North America); the Mediterranean Sea; Sitka; Greenland.

\section{Baseodiscus hemprichi (EHRENBERG), 1831}

Eupolia hemprichi: Bürger, 1895; PunNett, 1901 and 1903; Gravely, 1927.

Baseadiscus hemprichi: Bürger, 1904; PUnNetT, 1909-1910; YAMAOKA, 1939.

One large specimen extended up to 8 meter in length was collected by Mr. URA at Tôshima in July, 1950.

Distribution. Tôshima, in front of the Seto Laboratory at Shirahama, and Nakanoshima (by ТокıокA) in Tokara Islands, Japan; Suô and Kizan, northeastern coasts of Formosa (by HrRo); the Red Sea, the Indian Ocean, the South Pacific Ocean and Malay Peninsula. 


\section{Nemertopsis gracilis COE, 1904}

(Fig. 2 A)

Nemertopsis gracilis: CoE, 1904, 1905 and 1940.

The body is slender, nearly same in width throughout its length, and measures up to $100-120 \mathrm{~mm}$ long. The head is demarcated from the succeeding portion of the body. The body is dull yellow in colour and with two narrow dark brown stripes throughout the dorsal surface of the body. The stripes extend anteriorly to nearly the tip of the head and are distinct in colour in the anterior half, but gradually become paler posteriorly. Four large ocelli arranged in a rectangular shape are situated outside the stripes.

A


B


Fig. 2. A. Nemertopsis gracilis COE. 1. Dorsal view of the anterior portion of the body. 2. Lateral view of the central stylet and the basis of the proboscis.

B. Amphiporus insolitus sp. nov. Dorsal view of the anterior portion of the body.

C. Tetrastemma verinigrum var. meridialis nov. Dorsal view of the anterior portion of the body.

Internal structure. The cephalic glands are enormously well developed and extend posteriorly beyond the brain to the hind end of the proboscis sheath or to the most anterior reproductive organs. The proboscis sheath is limited to about one-fifth the length of the body. The basis of the central stylet is short, nearly cylindrical in 
form and conical in a slightly anterior portion, being $0.047 \mathrm{~mm}$ long and $0.025 \mathrm{~mm}$ wide in a specimen. Each of two lateral pouches contains two stylets. The cerebral sense organs are small and situated short distance in front of the brain. The central stylet is short, being one-third the length of the basis. The intestinal caecum is anteriorly devoid of diverticula and is separated from the brain by its length. The dorsal ganglion is about two times the size of the ventral ganglion. The lateral nerves run posteriorly from the back of the ventral ganglion along the lateral side of the gut.

Remarks. The difference of the body between the present material and the American one lies in the distance between the anterior end of the intestinal caecum and the posterior end of the brain; the distance of the latter one is several times the length of the brain. N. bivittata (DELle CHIAJE) reported by Bürger (1904) nearly agrees with this species in both outer and inner structure of the body except for the shape of the stylets which are lobed or five-parted in N. bivittata.

Habitat. Commonly found in the mantle cavity of Mitella mitella (by UTinomi).

Distribution. Shirahama, Japan; Pacific Grove, California.

\section{Amphiporus punctatulus COE, 1905}

Amphiporus punctatulus: CoE, 1905 and 1940; IwATA, 1951, 1952 and 1954.

Habitat. Commonly found under stones between the tide marks.

Distribution. Shirahama, Shimoda and Tomioka in Honshu, and Oshoro and Rishiri Island in Hokkaido, Japan; Kurile Islands; Isthmus Cave, Catalina Islands, California, U. S. A.

\section{Amphiporus insolitus sp. nov.}

(Figs. 2 B \& 3)

The body is short and slender, anteriorly convex dorsally and posteriorly flattened dorso-ventrally in the transverse section of the body, and about $4 \mathrm{~cm}$ long and $0.7 \mathrm{~mm}$ wide. The head is somewhat wider than the rest of the body. The body is dark brown in colour and devoid of any markings, and is paler towards the anterior portion of the body except the head. The ocelli are not found through the skin, but a pair of small ocellus-like spots is situated at the lower portion of the lateral side of the rhynchodeal opening.

Internal structure. The cephalic glands are voluminous, extending backward to the posterior portion of the brain along its under side, though disintegrated dorsally in the portion of the cerebral sense organs. Several ducts of the cephalic glands are situated above the anterior portion of the rhynchodaeum and lead their tips into the rhynchodeal opening. The cerebral sense organ is rather large and situated at the portion far ahead the brain, opening externally by a narrow canal on latero-ventral 
surface of the subterminal portion of the head. The intestinal caeca are entirely wanting. Parenchyma is well developed in stomachic region, extending anteriorly to the portion of the cerebral sense organs. The intestinal diverticula are laterally divided into short and broad branches. The circular muscle fibers run dorso-ventrally in the parenchymatous tissue and encircle the inner side of the longitudinal muscle layer. The outer circular muscle layer of the proboscis sheath is rather well developed throughout the body, being about three times the thickness of the outer circular muscle layer of the body wall. The proboscis sheath extends posteriorly to the hind end of

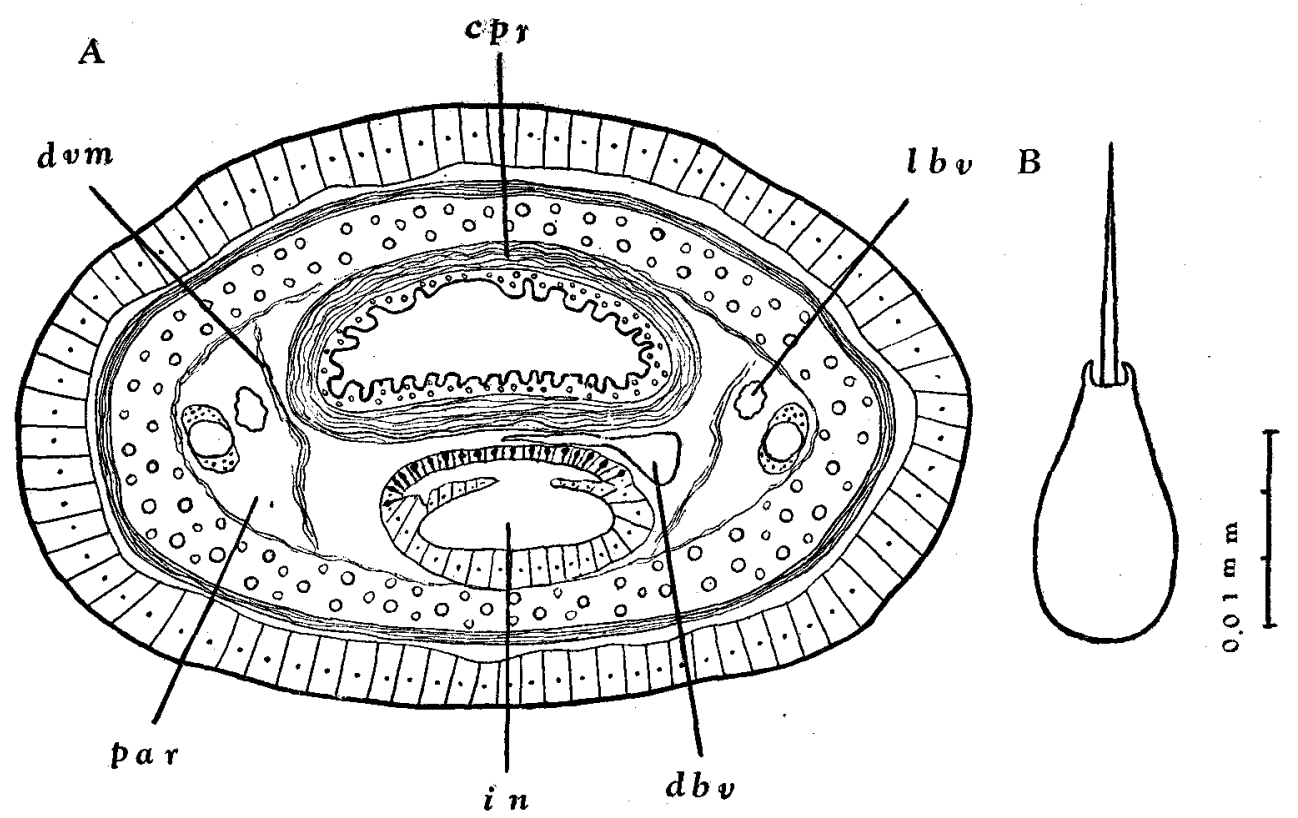

Fig. 3. Amphiporus insolitus sp. nov. A. Cross section of the portion of the posterior end of the stomach. B. Lateral view of the central stylet and the basis of the proboscis; $c p r$. circular muscle layer of the proboscis sheath, $d b v$. dorsal blood vessel, $d v m$. dorsoventral muscle fibres, $l b v$. lateral blood vessel, in. intestine, par. parenchyma.

the body and is provided with 14 distinct nerves. Each of two lateral pouches contains one or two stylets, one of which is $0.037 \mathrm{~mm}$ long. The basis of the central stylet is oval in shape and nearly same the length of the accessory stylets. The nephridia composed of several branched ducts extend posteriorly from the anterior portion of the brain to the posterior portion of the stomach. A pair of efferent ducts are sent out from the anterior portion of nephridia, and each of them opens externally on the lateral surface of the body.

Remarks. It is remarkable that this species has a pair of ocelli, a well developed 
parenchymatous tissue, dorso-ventral muscle fibers and a few muscle fibers surrounding the inner side of the longitudinal muscle layer, and is devoid of the intestinal caeca which are one of the important characters of the genus Amphiporus.

Habitat. Only one specimen was found under a stone near low tide mark.

Distribution. Kushimoto.

\section{Tetrastemma verinigrum var. meridianum nov.}

(Fig. 2C)

Tetrastemma verinigrum: IWATA, 1954.

The body is short and slender, rounded in the transverse section of the body, being about $5 \mathrm{~cm}$ long and $1 \mathrm{~mm}$ wide. The head is anteriorly rounded in outline from above and not demarcated from the succeeding portion of the body. The body is brown and posteriorly grayish brown in colour owing to the colour of the intestine. A large shield-shaped marking is found on the dorsal surface of the head and is black in colour. Two large ocelli are arranged at a short distance behind the marking, and other two ones which are situated under the marking are found in the anterior portion of the head. They are arranged in a rectangular shape.

Internal structure. The cephalic glands are well developed in three portions of the rhynchodaeum except the ventral side, extending posteriorly to the portion far ahead the brain. The cerebral sense organ is voluminous and extends from the portion slightly ahead the brain backward to the anterior portion of the brain along its latero-ventral surface. A short and narrow canal which is sent out from the cerebral sense organ, opens externally in the middle portion of the lateral surface between the tip of the head and the anterior portion of the brain. The diverticula of the intestinal caecum are rather long, extending from the posterior end of the brain to the posterior portion of the stomach. The intestinal diverticula do not branch laterally. The gonads are regularly arranged between the intestinal diverticula. Parenchyma is entirely wanting in the anterior portion of the body. The nephridia extend from the anterior portion of the brain to the posterior portion of the stomach and send off a pair of efferent ducts in the anterior portion, opening externally on the latero-ventral surface of the body.

Remarks. The present new variety agrees with $T$. verinigrum in having a black cephalic marking, but differs from the latter in colour, the longer diverticula of the intestinal caecum and the position of the cerebral sense organs.

Habitat. One specimen was found under a stone near low tide mark.

Distribution. Kushimoto and Oshoro in Hokkaido. 


\section{LITERATURE}

Bürger, O. 1895. Die Nemertinen des Golfes von Neapel. Fauna und Flora des Golfes von Neapel, vol. 22. 1904. Nemertini. Das Tierreich, Bd. 20.

CoE, W. R. 1901, Papers from the Harriman Alaska Expedition. 20, The nemerteans. Proc. Wash. Acad. Sci, vol. 3. 1904. The nemerteans. Harriman Alaska Exped., vol. 11. 1905. Nemerteans of the west and northwest coasts of America. Bull. Mus. Comp. Zool., vol. 47. 1940. Revision of the nemertean fauna of the Pacific coasts of north, central, and northern south America. Allan Hancock Pacific Exped., vol. 2, no. 13.

Gravely, F. H. 1927. Nemertinea. The littoral fauna of Krusadai Island in the Gulf of Manaar. Bull. Madras Govt. Mus., Nat. Hist. Sect. N. S., vol. 1, no. 1.

Griffin, B. B. 1898. Description of some marine nemerteans of Puget Sound and Alaska. Ann. N. York Ac., vol. 11.

IwatA, F. 1951. Nemerteans in the vicinity of Onomichi. Jour. Fac. Sci. Hokkaido Univ., ser. 6, Zool., vol. 10, no. 2. 1952. Nemertini from the coasts of Kyusyu. Jour. Fac. Sci. Hokkaido Univ., ser. 6, Zool., vol. 11, no. 1 . 1954. The fauna of Akkeshi Bay. XX. Nemertini in Hokkaido (Revised Report). Jour. Fac. Sci. Hokkaido Univ., ser. 6, Zool., vol. 11, no. 3.

Joubin, M. L. 1905. Note sur quelques Némertiens recueillis en Basse-Californie par M. Diguet. Bull. du Muséum National d' Histoire Naturelle, tom. 11.

PUnNetr, R. C. 1901. On two British nemerteans. Quart. Journ. Micr. Sci., vol. 44. 1903. Nemerteans. The Fauna and Geography of the Maldive and Laccadive Archipelagoes, vol. 1. 1909-1910. On some nemerteans from the Eastern Indian Ocean. Trans. Linn. Soc. London, Zool. ser. 2, vol. 13.

Stimpson, W. 1855. Description of some of the new marine Invertebrata from the Chinese and Japanese Seas. Proc. Acad. Nat. Sci. Philadel., vol. 7. 1857. Prodromus descriptionis animalium evertebratorum, quae in expeditione ad oceanum Pacificum septemtrionalum, .......... Proc. Acad. Nat. Sci. Philadel.

TAKAKURA, U. 1898. Classification of Nemertini in the vicinity of Misaki (In Japanese). Zool. Mag. (Tokyo), vol. 10.

Wheeler, J. F. G. 1934. Nemerteans from the South Atlantic and Southern Oceans. Discovery Reports, vol. 9.

YamAOKa, T. 1939. Two nemerteans from Formosa. Annot. Zool. Japon., vol. 18, no. 4. 1940 a. The Fauna of Akkeshi Bay. IX. Nemertini. Jour. Fac. Sci. Hokkaido Univ., ser. 6, Zool., vol. 7 , no. 3 .

1940 b. Two nemerteans from the Riukiu Islands. Annot. Zool. Japon., vol. 19, no. 1. 